\title{
ACCELERATED TESTS OF ORGANIC PROTECTIVE COATINGS
}

\author{
By Percy H. Walker and E. F. Hickson
}

\section{ABSTRACT}

This paper deseribes the equipment used at the Bureau of Standards in accelerated tests of paints, varnishes, lacquers, bitumens, etc.

A great variety of organic coatings, when subjected to a cycle of alternate exposure to light from an inclosed carbon arc, water spray and ozonized air, were shown to exhibit the same kind of decay as observed on exposure to the weather.

The difficulty of determining the relative condition of exposure tests is discussed, and methods for quantitatively determining when the coating ceases to protect are described.

\section{CONTENTS}

I. Introduction

Page

1. Description of apparatus_...

2. Light source

3. Rain

4. Temperature changes (refrigeration) _..... 4

5. Gases_...

6. Method of preparing test panels

7. Description of exposure cycle_.... 5

III. Methods of determining extent to which disintegration has taken place

1. Observation by experts

2. Permeability to water vapor 9

3. Permeability to air

4. Electrical conductivity test

5. Use of milliammeter _.. 14

6. Qualitative method for detecting pinholes, etc., in paints__-_ 15

IV. Summary

\section{INTRODUCTION}

The purpose of this paper is to describe the equipment in use at the Bureau of Standards for making accelerated tests of organic protective coatings, and to discuss the results obtained by its use.

The rapid testing of coatings to determine their probable relative durability under service conditions involves two distinct problems. It is necessary first to subject the coatings to conditions which will cause rapid deterioration of the character encountered in actual service. It is then necessary to determine the degree to which the 
coatings have failed under the test conditions. The equipment now in use for subjecting test coatings to a variety of agencies which cause deterioration will first be described. Methods of determining the degree of deterioration will then be discussed.

\section{METHODS USED TO CAUSE ACCELERATED DISINTE- GRATION}

Light, moisture, temperature changes, and varying small accidental additions to normal air are the important causes of decay of paint, varnish, and other organic protective coatings. In general, the most important of these is light.

\section{DESCRIPTION OF APPARATUS}

The chamber for exposure to light and moisture consists of a rotating cylinder made of No. 16 gauge galvanized iron, $76 \mathrm{~cm}$ (30 inches) in diameter, $38 \mathrm{~cm}$ (15 inches) high, open at both ends, with the light suspended in the center. This size was selected so as to bring the light as near the panels as possible, at the same time avoiding too high temperatures. The cylinder has a capacity of sixty 7.5 by 15 cm (3 by 6 inch) panels.

The test panels are placed in two tiers immediately opposite the light inside the cylinder, the panels thus being $38 \mathrm{~cm}$ (15 inches) from the center of the light source. This gives a temperature of about 52 to $55^{\circ} \mathrm{C}$. at the panels with the type of lamp used. Thirty slotted holders, $7.5 \mathrm{~cm}$ ( 3 inches) wide and about $33 \mathrm{~cm}$ (13 inches) long for panels $7.5 \mathrm{~cm}$ ( 3 inches) wide, are attached to the inner surface of the open cylinder. The exposure cylinder is provided with water sprays, so that it is possible to expose the panels in succession to intense light and to a variety of moisture conditions. A pan placed about $5 \mathrm{~cm}$ below the bottom of the cylinder contains water and serves to keep the temperature down to about $52^{\circ} \mathrm{C}$. next to the panels, as well as to humidify the air. Separate cabinets for exposure to gases and refrigeration are provided.

\section{LIGHT SOURCE}

In selecting a source of light it is advisable to choose a powerful light and one whose average intensity and spectral distribution will remain fairly constant. Whether or not the relative resistance to exposure of various coatings will be the same under sunlight as under a light of very different spectral distribution has never been determined, and until it is determined it seems desirable to use a light source as similar to sunlight as possible. Owing to absorption by the earth's atmosphere, no radiation of wave length shorter than $290 \mathrm{~m} \mu$ reaches the earth. ${ }^{1}$ The quartz-tube mercury-arc light which

1 B. S. Sci. Paper No. 539, p. 592. 
B. S. Journal of Research, RP1

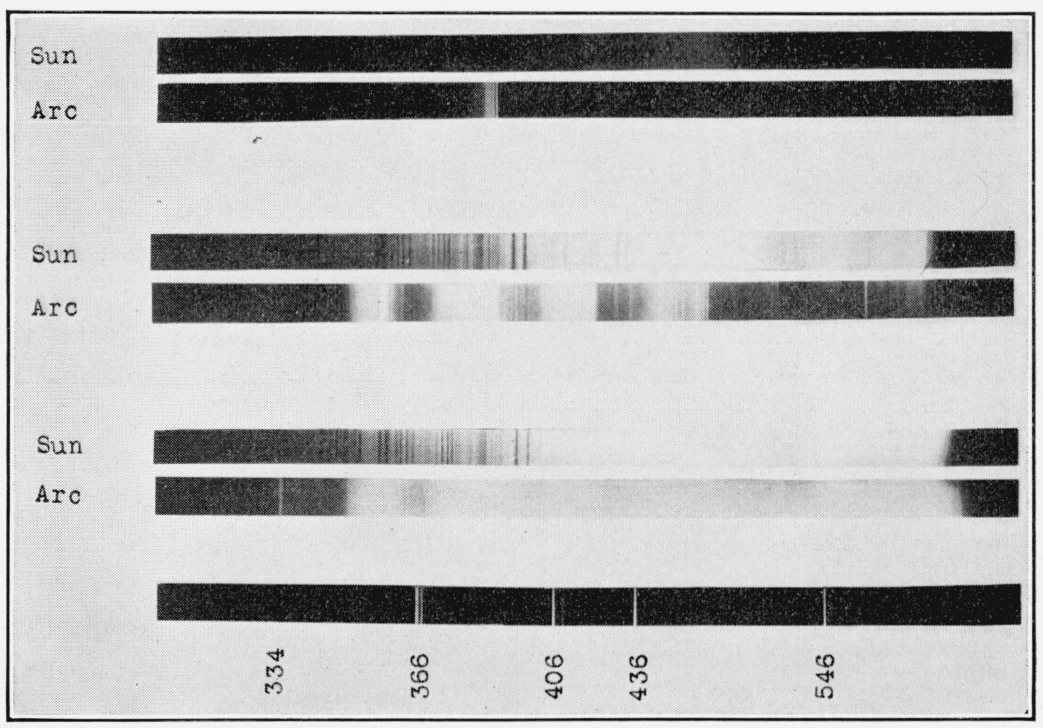

FIG. 1.-Spectra of sun and of long-flame carbon arc, each at three different exposures

The pairs of exposures are at comparable times. The numbers give the wave lengths in millimicrons of the mercury arc lines used for reference 
B. S. Journal of Research, RP1

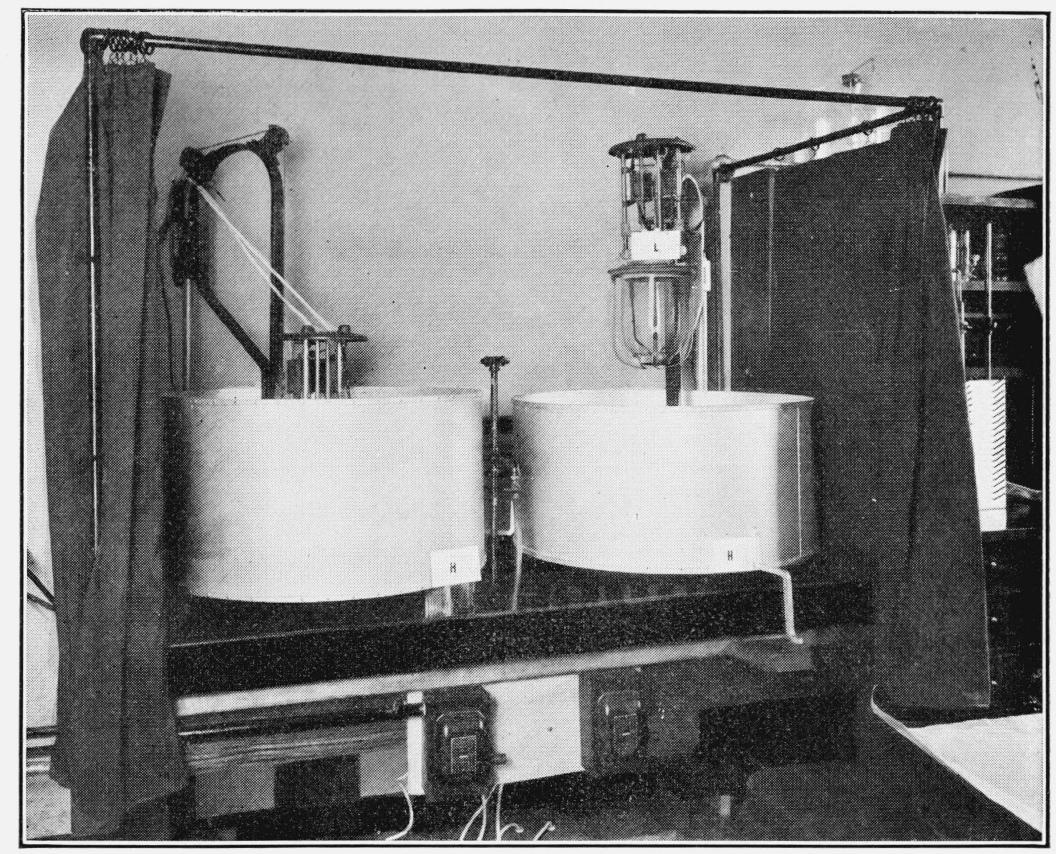

FIG. 2.-Light exposure equipment

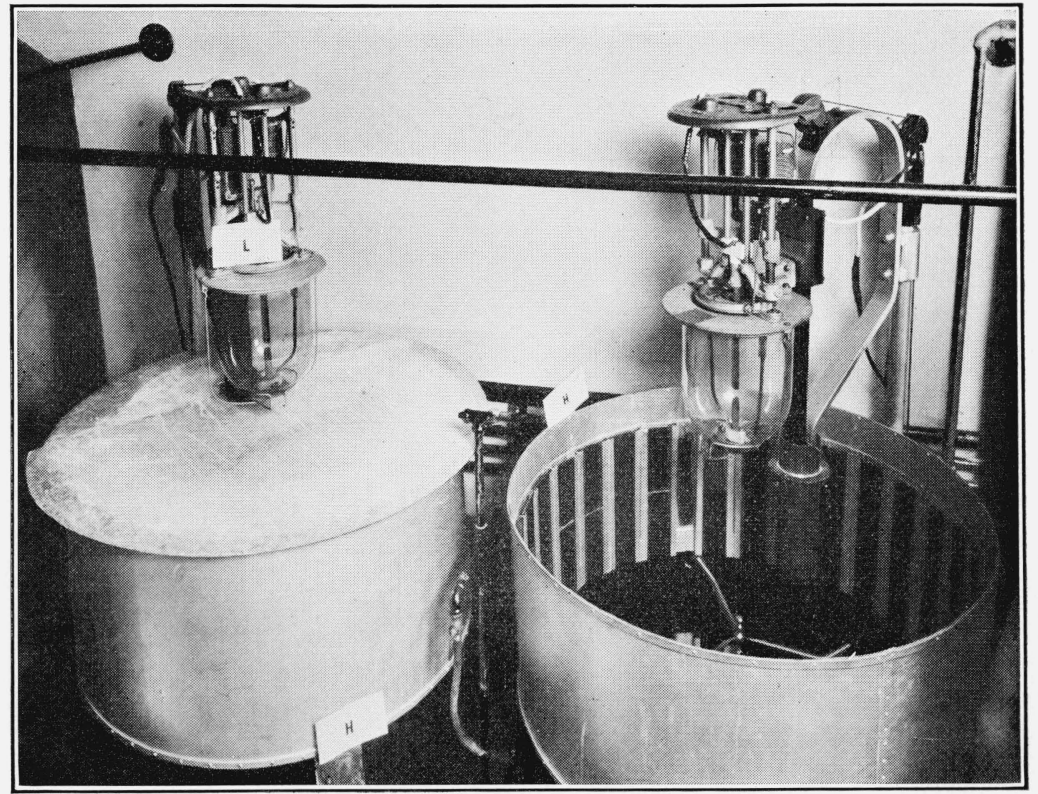

FIG. 3.-Water spray (rain) equipment 
has been advocated by Nelson and others ${ }^{2}$ has not been used as a source of light in this work. Most of the work recorded in this paper has been done with an inclosed type carbon-are light operated at 220 volts d. c. at 13 amperes. Since the light is of the inclosed type the carbons can be operated with this current about 34 hours without renewal. The glass globe should be cleaned on each renewal of the electrodes.

Figure 1 shows (in comparison with sunlight) the spectrum of the arc used with the glass globe in position, taken on a panchromatic film in a quartz spectrograph. It is to be noted that the band spectra of both the arc and sun apparently become more continuous as the time of exposure is increased. Note also that while this are spectrum shows much radiation in the moderate ultra-violet (350 to $400 \mathrm{~m} \mu$ ) it shows none of the very short waves not found in sunlight but given by the quartz mercury arc. The electrodes used are of solid carbon $12.7 \mathrm{~mm}$ in diameter. The glass globe is opaque to ultra-violet wave lengths less than $320 \mathrm{~m} \mu$ and infra-red radiation longer than about $4,500 \mathrm{~m} \mu$. The total radiation at a distance of $38 \mathrm{~cm}$ (15 inches) from the center and at right angles to the are on 12.6 amperes is 0.075 watt per $\mathrm{cm}^{2}$. This is distributed in the spectrum as shown in Table 1.

\section{TABLE 1.-Spectral distribution of carbon-arc light with glass globe}

\begin{tabular}{|r|r|}
\hline Spectral range & $\begin{array}{r}\text { Per cent of } \\
\text { the total } \\
\text { radiation }\end{array}$ \\
\cline { 2 - 2 } 320 to $360 \mathrm{~m} \mu_{-}$ & \\
360 to $480 \mathrm{~m} \mu \ldots$ \\
480 to $600 \mathrm{~m} \mu \ldots$ \\
600 to $1,400 \mathrm{~m} \mu \ldots$ \\
1,400 to $4,200 \mathrm{~m} \mu \ldots$ \\
4,200 to $12,000 \mathrm{~m} \mu \ldots \ldots$ \\
\end{tabular}

The large amount of infra-red of wave lengths 4,200 to $12,000 \mathrm{~m} \mu$ emanates principally from the glass globe which becomes heated by the arc, and is different in spectral composition from the infra-red from the incandescent arc. Owing to unsteadiness of the arc, which travels around the electrode, the radiation measurements varied by 20 per cent. A steadier are would be obtained by operating at 20 amperes, but at this current the carbons would be consumed too rapidly.

Figure 2 shows two light units. In the left-hand unit the light is shown in position in the center of the cylindrical sample holder, $H$.

2 Proc. Am. Soc. Test. Mtls., 22, Pt. II, p. 485; 1922; Proc. Am. Soc. Test. Mtls., 24, Pt. II, p. 920; 1924; Proc. Am. Soc. Test. Mtls. 26, Pt. II, p. 563; 1926. 
In the right-hand unit the light, $L$, is shown raised out of the cylindrical holder.

\section{RAIN}

In addition to light exposure, the panels should be subjected from time to time to several hours of vigorous spraying with warm $\left(100^{\circ} \mathrm{F}\right.$.) water. The panels can be removed to a special chamber for this purpose, but it is more convenient to produce this artificial rain in the chamber used for the light exposure. For this purpose the light is raised out of the cylinder, a common rotating lawn sprinkler put in, the bottom of the bracket supporting the light is protected from spray by a brass cylinder and the top of the cylinder holding the samples covered by galvanized iron covers.

Figure 3 shows the arrangement for spraying the panels with water. The right-hand unit with the cover removed shows the rotating spray, the slots containing test panels, and the protecting tube over the lower part of the lamp support. The left-hand unit shows the lid in place.

In order to simulate a hot, humid climate a fixed water spray has been mounted in the tank in such a manner that it may function while the lights are operating. Connections for this spray are made at the tee above and between the two tanks. (See fig. 3.)

The light cylinders are also now made to rotate slowly, at the rate of three revolutions per hour. Thus with the lights in operation and in position (see fig. 2), a gentle spray can wet the test surfaces periodically while exposed to the light.

\section{TEMPERATURE CHANGES (REFRIGERATION)}

An ammonia coil about 27 by 47 by $40 \mathrm{~cm}$ in an insulated chamber that can be cooled to $-25^{\circ} \mathrm{C}$. $\left(-13^{\circ} \mathrm{F}\right.$.) is used to quickly chill the test panels.

The test panels on removal from the light chamber are placed on the rack shown, and the rack with samples is placed in the refrigerator and left there for one hour and then removed.

\section{GASES}

It is most convenient to transfer the panels to a separate cabinet for exposure to various gas mixtures. Such a cabinet for exposure to ozonized air is shown in Figure 4. Air is forced, by means of the small motor-driven fan shown in the lower left corner, through a silica gel dehydrator, then through a calcium chloride bottle, which serves to indicate that the silica gel is working efficiently, to the ozonizing apparatus and thence to the glass chamber on the right for holding the panels. Some water is placed in the bottom of this 
B. S. Journal of Research, RP1

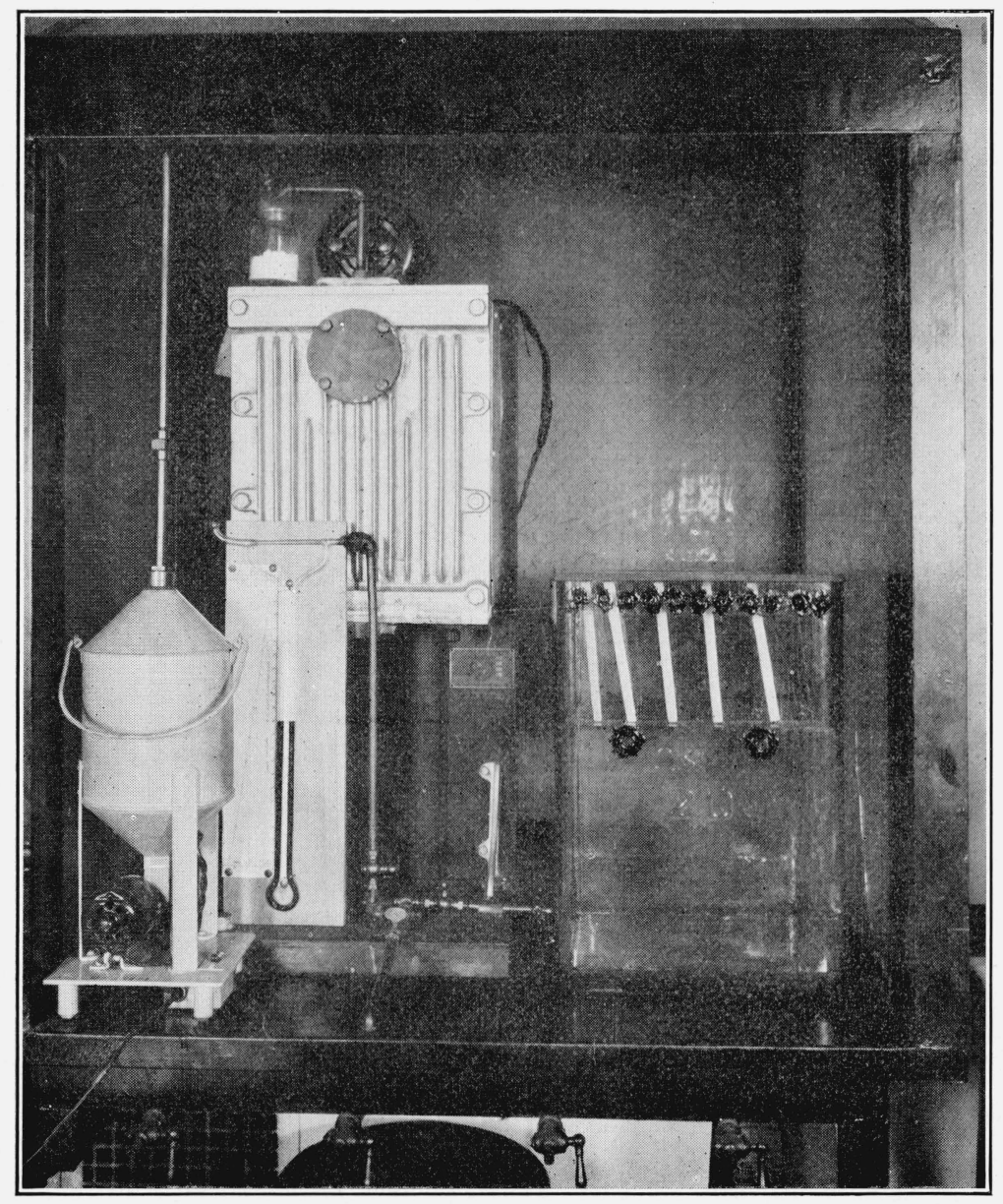

FIG. 4.-Cabinet for exposing to ozonized air 


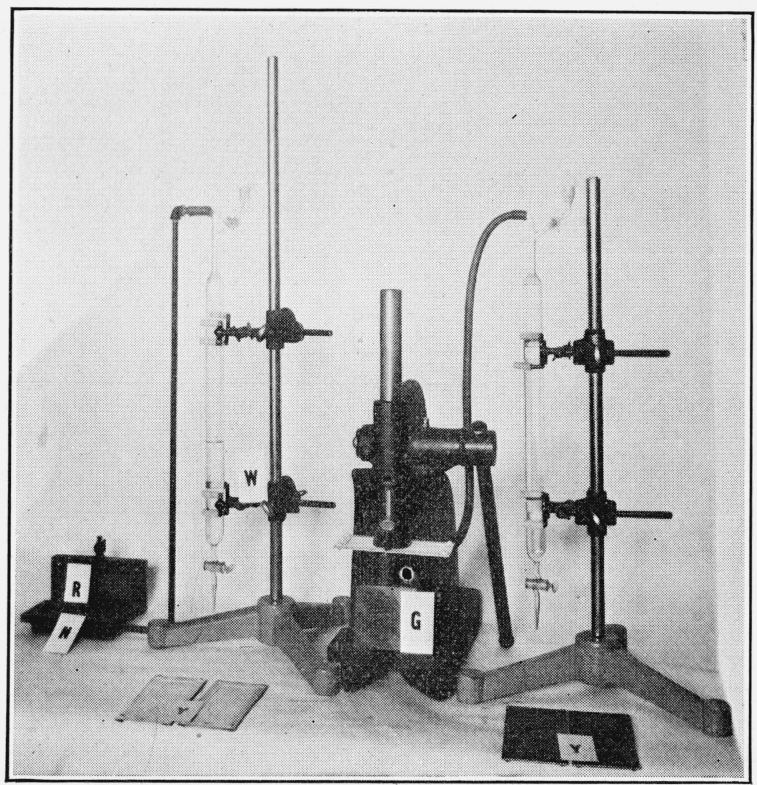

FIG. 5.-A pparatus for determining breakdown of film by passing air through it

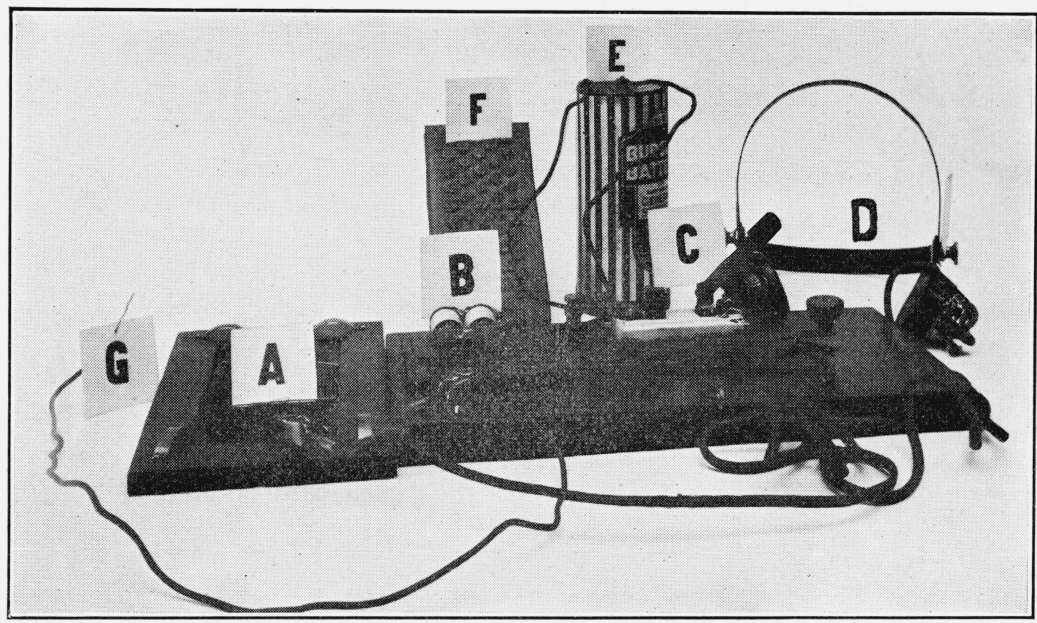

FIG. 6.-Photograph and wiring diagram of Wilson's apparatus for determining end point of paint failures

$A$, Steel wool contact frame. $B$, Buzzer. $C$, Switch. $D$, Head phones. $E$, Dry cell. $F$, Rubber

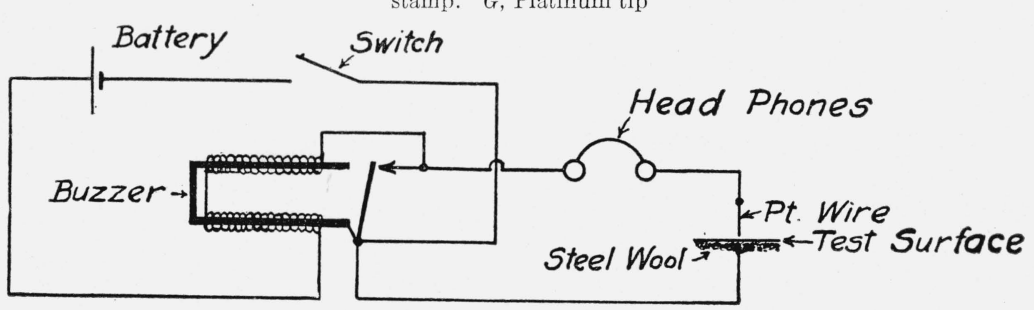

FIG. 7.-Wiring diagram 
glass chamber to moisten the ozonized air. By suitable manipulation of the stopcocks in the pipe line the rate of flow can be determined by the flow meter, shown to the right of the silica gel holder, and samples for determining the ozone concentration can be taken through the pipe projecting toward the front. This equipment delivers about 660 liters per hour of air containing about 0.08 per cent of ozone by volume.

\section{METHOD OF PREPARING TEST PANELS}

It is a waste of time to make tests on single coats of protective coatings. This can be readily demonstrated by brushing and flowing paints on glass and, after drying, examining by transmitted light. It is advisable to always use at least two and generally three coats on the exposed test surface.

When using wood or metal, the back and edges of the panels are given three coats of aluminum paint ( $25 \mathrm{~g}$ of polished aluminum powder to $100 \mathrm{ml}$ of long-oil water-resisting spar varnish). This aluminum paint is very waterproof and gives excellent protection to both wood and steel. Since, during exposure, it is not exposed to light it may be relied upon to last longer than any material being tested on the exposed surface.

In addition to tests on wood or metal, it is advisable to apply the material to 100 -mesh wire gauze or to cotton cloth. This will be discussed later in connection with methods of determining the extent to which disintegration has taken place.

\section{DESCRIPTION OF EXPOSURE CYCLE}

Since light is the most important destructive agency in exposure tests, it seemed necessary to make use of as much light as possible. Therefore, the night hours (17 hours) were given over to light exposure. The idea in subjecting the panels to air containing a small amount ( 0.08 per cent) of ozone was to accelerate surface oxidation. In using refrigeration, the desired factor seemed to be a rapid change in temperature, rather than any definite time of exposure to the low temperature. The refrigerating unit was not assembled until some time after the light-exposure cylinder and gas chamber were made. In some of the earlier tests the panels were, therefore, not exposed to sudden temperature changes. The following tentative schedule shows the weathering cycle now in use:

Monday:

Ozonized air (wet atmosphere)

Water (tap water at about $100^{\circ} \mathrm{F}$., from a rotating spray) .

$31 / 2$ hours ( 9.30 to 1$)$.

Light (carbon are)

3 hours (1 to 4$)$.

17 hours (4 to 9 ). 
Tuesday:

Refrigeration $\left(-10^{\circ} \mathrm{F}.\right)$

Ozonized air

Water

1 hour (9.30 to 10.30$)$.

Light

$21 / 2$ hours (10.30 to 1$)$.

3 hours (1 to 4 ).

17 hours (4 to 9 ).

Wednesday:

Water

3 hours (9.30 to 12.30 ).

Refrigeration

1 hour (12.30 to 1.30 ).

Ozonized air

$2 \frac{1}{2}$ hours ( 1.30 to 4 ).

Light.

17 hours (4 to 9 ).

Thursday:

Refrigeration ( $-10^{\circ}$ F.)

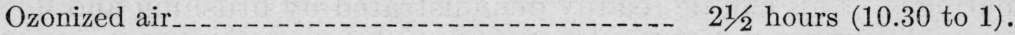

Light_......

Friday:

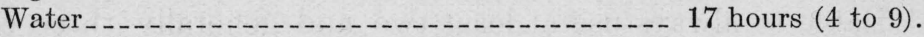

Refrigeration $\left(-10^{\circ}\right.$ F.) -

Ozonized air_._.

Water_........

Light_._.

Saturday:

Ozonized air._.......

Water_......

Sunday:

Light_.

Light.

24 hours (9 to 9 Monday).

Total operating hours $=165$ divided thus: Hours Per cent

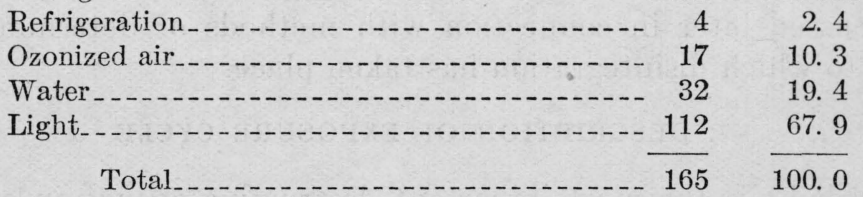

It will be noted that in this schedule only 165 out of 168 hours are accounted for. The remaining three hours are used for the inspection of the panels.

\section{METHODS OF DETERMINING EXTENT TO WHICH DISINTEGRATION HAS TAKEN PLACE}

\section{OBSERVATION BY EXPERTS}

Competent experienced observers frequently draw widely varying conclusions from inspection of the same panels, and the same observers draw varying conclusions at different times. This is well illustrated by the following:

One of the most carefully executed and widely known series of exposure tests was the Havre de Grace Bridge test of the American Society for Testing Materials. Nineteen paints designed as protective coatings for steel were used. Each of these paints was applied in three spreading rates $-600,900$, and 1,200 square feet per 
gallon. Triplicate panels were used for each spreading rate, making nine panels for each paint. The panels were exposed in November, 1906. The work was done with the utmost care and the various inspections were made by competent men experienced in such work. The divergent opinions of competent observers mentioned above are well illustrated in the following selection of 5 of these 19 paints. $^{3}$ The inspection was made May 5, 1910. The examination of the panels was divided into three heads, viz:

TABLE 2.-Ratings of 5 out of 19 paints inspected May 5, 1910

\begin{tabular}{|c|c|c|c|c|c|c|c|c|c|}
\hline Paint & $\begin{array}{l}\text { Exam- } \\
\text { ined } \\
\text { for- }\end{array}$ & Aiken & $\begin{array}{c}\text { Mac- } \\
\text { Naughton }\end{array}$ & Tassin & $\begin{array}{l}\text { Thomp- } \\
\text { son }\end{array}$ & Hume & Average & $\begin{array}{l}\text { Maxi- } \\
\text { mum }\end{array}$ & $\begin{array}{l}\text { Mini- } \\
\text { mum }\end{array}$ \\
\hline $2 \ldots$ & $\left\{\begin{array}{l}\mathrm{A} \\
\mathrm{B}_{\ldots} \\
\mathrm{C}\end{array}\right.$ & $\begin{array}{c}8 \\
10 \\
6.44\end{array}$ & $\begin{array}{l}9 \\
6 \\
6\end{array}$ & $\begin{array}{ll}1 & 1 \\
1 & 1 \\
1 & 1\end{array}$ & $\begin{array}{l}8 \\
8 \\
4.33\end{array}$ & $\begin{array}{l}9 \\
9 \\
4.66\end{array}$ & $\begin{array}{l}8.5 \\
8.2 \\
5.3\end{array}$ & $\begin{array}{c}9 \\
10 \\
6.44\end{array}$ & $\begin{array}{l}1 \\
1 \\
1\end{array}$ \\
\hline 10. & $\left\{\begin{array}{l}A_{-} \\
B_{-} \\
\mathrm{C}_{\ldots}\end{array}\right.$ & $\begin{array}{r}8 \\
9 \\
10\end{array}$ & $\begin{array}{l}9 \\
6 \\
9\end{array}$ & $\begin{array}{l}10 \\
10 \\
10\end{array}$ & $\begin{array}{l}6 \\
6 \\
8\end{array}$ & $\begin{array}{l}9 \\
9 \\
9\end{array}$ & $\begin{array}{l}8.4 \\
8.0 \\
9.2\end{array}$ & $\begin{array}{l}10 \\
10 \\
10\end{array}$ & $\begin{array}{l}6 \\
6 \\
8\end{array}$ \\
\hline 11. & $\left\{\begin{array}{l}A_{---} \\
B_{---} \\
C_{---}\end{array}\right.$ & $\begin{array}{r}9 \\
9 \\
10\end{array}$ & $\begin{array}{l}9 \\
6 \\
8\end{array}$ & $\begin{array}{l}10 \\
10 \\
10\end{array}$ & $\begin{array}{l}6 \\
7.14 \\
7.14\end{array}$ & $\begin{array}{l}7 \\
9.66 \\
9\end{array}$ & $\begin{array}{l}8.2 \\
8.4 \\
8.8\end{array}$ & $\begin{array}{l}10 \\
10 \\
10\end{array}$ & $\begin{array}{l}6 \\
6 \\
7.14\end{array}$ \\
\hline 13. & $\left\{\begin{array}{l}A_{--} \\
\mathrm{B}_{--} \\
\mathrm{C}_{-}\end{array}\right.$ & $\begin{array}{c}8 \\
10 \\
8.55\end{array}$ & $\begin{array}{r}10 \\
10 \\
7\end{array}$ & $\begin{array}{l}10 \\
10 \\
10\end{array}$ & $\begin{array}{r}8 \\
10 \\
6\end{array}$ & $\begin{array}{r}9 \\
10 \\
9\end{array}$ & $\begin{array}{c}9 \\
10 \\
8.1\end{array}$ & $\begin{array}{l}10 \\
10 \\
10\end{array}$ & $\begin{array}{r}8 \\
10 \\
6\end{array}$ \\
\hline 14. & $\left\{\begin{array}{l}\mathrm{A} \\
\mathrm{B}_{\ldots} \\
\mathrm{C}_{\ldots}\end{array}\right.$ & $\begin{array}{r}9 \\
10 \\
10\end{array}$ & $\begin{array}{l}9 \\
9 \\
8\end{array}$ & $\begin{array}{l}10 \\
10 \\
10\end{array}$ & $\begin{array}{r}8 \\
10 \\
6\end{array}$ & $\begin{array}{r}8 \\
10 \\
9\end{array}$ & $\begin{array}{l}8.8 \\
9.8 \\
8.6\end{array}$ & $\begin{array}{l}10 \\
10 \\
10\end{array}$ & $\begin{array}{l}8 \\
9 \\
6\end{array}$ \\
\hline
\end{tabular}

1 These values were not considered in computing the average of paint No. 2 .

A. Chalking.

B. Checking, cracking, "alligatoring," etc.

C. General surface condition, with a marking for each as follows: Excellent, 10 to 8.

Good, 8 to 6.

Fair, 6 to 4 .

Poor, 4 to 2 .

Failure, 2 to 0.

As far as possible members of the subcommittee were requested to pair off with such other members of Committee D-1 who were present though not of the subcommittee on inspection. Those of the subcommittee present were $* W$. A. Aiken, chairman, ${ }^{*} \mathrm{G}$. W. Thompson, *M. MacNaughton, *A. P. Hume, Anderson Polk, A. H. Sabin, *Wirt Tassin. Those marked with an asterisk (*) sent in individual reports. A. H. Sabin was the only one who collaborated

3 Taken from Proc. A. S. T. M., 10, pp. 105-106; 1910. 
with any other member of the subcommittee; he was with the chairman, who also was accompanied by Mr. Gibboney, of Committee D-1. The individual marks were averaged from all nine panels, covering three rates of spreading.

Another lot of 51 panels was inspected by a committee of seven members on April 15, 1910, ${ }^{4}$ and by a committee of four on June 28, $1911 .^{5}$ Three of the four members of the 1911 committee were also members of the 1910 committee. In the 1910 ratings 18 panels had a maximum rating of 10 and only 6 of these a minimum rating as high as 8 and 8 had a minimum rating of 6 or less. Sixteen panels had a maximum rating of 9 , with only 4 of these having a minimum rating of 8 , and 8 having a minimum rating of 5 or less. The variation in the remaining 17 panels is proportionally as great, with the exception of 2 which were marked " 0 " by all members of the committee. Table 3 showing results on 7 of these panels was compiled from the two reports.

TABLE 3.-Ratings of 7 out of 51 paints

\begin{tabular}{|c|c|c|c|c|c|}
\hline Paint No. & Date of inspection & W. H. Walker & P. H. Walker & Gardner & Chapman \\
\hline 7 & $\left\{\begin{array}{l}\text { Apr. } 15,1910 \\
\text { June 28, } 1911\end{array}\right.$ & 3 & $\begin{array}{l}9 \\
4\end{array}$ & $\begin{array}{l}8 \\
5\end{array}$ & $\begin{array}{l}8 \\
7\end{array}$ \\
\hline 24 & $\left\{\begin{array}{l}\text { Apr. } 15,1910 \\
\text { June 28, } 1911\end{array}\right.$ & 5 & $\begin{array}{l}5 \\
7\end{array}$ & $\begin{array}{l}5 \\
2\end{array}$ & $\begin{array}{l}8 \\
8\end{array}$ \\
\hline 333. & $\left\{\begin{array}{l}\text { Apr. } 15,1910 \\
\text { June } 28,1911\end{array}\right.$ & 4 & $\begin{array}{l}7 \\
4\end{array}$ & $\begin{array}{l}9 \\
7\end{array}$ & $\begin{array}{l}9 \\
3\end{array}$ \\
\hline 555 & $\left\{\begin{array}{l}\text { Apr. } 15,1910 \\
\text { June 28, } 1911\end{array}\right.$ & 9 & $\begin{array}{l}9 \\
9\end{array}$ & $\begin{array}{l}8 \\
6\end{array}$ & $\begin{array}{l}9 \\
9\end{array}$ \\
\hline 777 & $\left\{\begin{array}{l}\text { Apr. } 15,1910 \\
\text { June } 28,1911\end{array}\right.$ & 7 & $\begin{array}{r}9 \\
10\end{array}$ & $\begin{array}{l}8 \\
5\end{array}$ & $\begin{array}{l}9 \\
7\end{array}$ \\
\hline $100_{-}$ & $\left\{\begin{array}{l}\text { Apr. 15, } 1910 \\
\text { June 28, } 1911\end{array}\right.$ & 5 & $\begin{array}{l}10 \\
8.5\end{array}$ & $\begin{array}{l}7 \\
4\end{array}$ & $\begin{array}{l}9 \\
8.5\end{array}$ \\
\hline $5555_{-}$ & $\left\{\begin{array}{l}\text { Apr. } 15,1910 \\
\text { June } 28,1911\end{array}\right.$ & 4 & $\begin{array}{l}1 \\
8\end{array}$ & $\begin{array}{l}0 \\
2\end{array}$ & $\begin{array}{l}3 \\
7\end{array}$ \\
\hline
\end{tabular}

Not only does this table show wide variation of opinion among competent observers examining the same panels, but it will be noted that all of the three observers who took part in both inspections rated one paint higher and one of the three rated two other paints higher in. 1911 than in 1910.

These and other similar examples convince the writers that one of the greatest needs for the study of paint and similar coatings is a

4. S. T. M. Proceedings, 10, p. 73; 1910.

5 A. S. T. M. Proceedings, 11, p. 192; 1911. 
method or methods for determining the time of breakdown of the coatings.

\section{PERMEABILITY TO WATER VAPOR}

Muckenfuss ${ }^{6}$ more than 14 years ago suggested determining permeability to water as a measure of the breakdown of paint coatings and described preliminary experiments. Dunlap ${ }^{7}$ has described a method used at the Forest Products Laboratory for determining the breakdown on weathering of paint on wood.

While using the same general idea of these investigations-determining the progressive change in permeability on weathering - the writers attacked the problem in different ways.

Twenty-three No. $100^{8}$ wire sieves $95 \mathrm{~mm}$ (33/4 inches) in diameter $\left(71.26 \mathrm{~cm}^{2}\right.$ area $)$ were given three coats as follows:

Sieves Nos. 1, 2, and 3, 8-gallon rosin-tung oil varnish.

Sieves Nos. 4, 5, and 6, 30-gallon rosin-tung oil varnish.

Sieves Nos. 7, 8, and 9, 50-gallon rosin-tung oil varnish.

Sieves Nos. 10, 11, and 12, the above 8-gallon varnish plus aluminum ( 2 pounds per gallon of varnish).

Sieves Nos. 13, 14, and 15, the above 30 -gallon varnish plus aluminum ( 2 pounds per gallon of varnish).

Sieves Nos. 16, 17, and 18, the above 50-gallon varnish plus aluminum (2 pounds per gallon of varnish).

Sieves Nos. 19, 20, and 21, white lead-linseed oil paint.

Sieves Nos. 22 and 23, lead-zinc linseed-oil paint, B. S. Circular No. 89.

One week was allowed for drying between coats, and 1 week after applying the last coat the sieves were fastened by rubber bands to glass petri dishes containing dry $\mathrm{CaCl}_{2}$, and then weighed. A blank consisting of a petri dish with dry $\mathrm{CaCl}_{2}$, fastened with rubber bands to another petri dish, was also weighed. The samples, with the blank, were then put in air saturated with water for 20 hours, then conditioned for 1 hour at $30^{\circ} \mathrm{C}$. and 32 per cent relative humidity and weighed again. This was repeated each day for 2 weeks. The average gains corrected for the blank were taken as the initial gains.

The coated sieves were then removed from the $\mathrm{CaCl}_{2}$ dishes, exposed to the weather at $45^{\circ}$ to the vertical facing south for a week, again fastened to the petri dishes over $\mathrm{CaCl}_{2}$, exposed to saturated air for 20 hours, conditioned for 2 hours, weighed, the weight corrected for the blank, removed from the dishes and again exposed out of doors. A similar sieve uncoated and exposed to the same high

\footnotetext{
6 J. Ind. and Eng. Chem., 5, p. 535; July, 1913.

${ }^{7}$ Ind. and Eng. Chem., 18, p. 1230; December, 1926.

8 The openings in No. 100 wire sieve cloth are $0.149 \mathrm{~mm}$; the diameter of the wiro is $0.102 \mathrm{~mm}$, and the area of the open space about 35 per cent of the total area.
} 
humidity condition showed an average passage of about $7.4 \mathrm{~g}$ of water. The results are shown in Table 4.

TABLE 4.-Permeability to water vapor of coatings on wire mesh exposed to weather

\begin{tabular}{|c|c|c|c|c|c|c|c|c|}
\hline Material (three coats) & $\begin{array}{c}\text { 8- } \\
\text { gallon } \\
\text { varnish }\end{array}$ & $\begin{array}{l}30- \\
\text { gallon } \\
\text { varnish }\end{array}$ & $\begin{array}{c}50- \\
\text { gallon } \\
\text { varnish }\end{array}$ & $\begin{array}{c}8- \\
\text { gallon } \\
\text { varnish } \\
+\mathrm{Al}\end{array}$ & $\begin{array}{c}30- \\
\text { gallon } \\
\text { varnish } \\
+\mathrm{Al}\end{array}$ & $\begin{array}{c}50- \\
\text { gallon } \\
\text { varnish } \\
+\mathrm{Al}\end{array}$ & $\begin{array}{l}\text { White } \\
\text { lead- } \\
\text { linseed } \\
\text { oil } \\
\text { paint }\end{array}$ & $\begin{array}{l}\text { Lead- } \\
\text { zine } \\
\text { paint } \\
\text { F. S. B. } \\
\text { Specifi- } \\
\text { cation } \\
\text { No. } 10\end{array}$ \\
\hline Initial water absorbed through film & 0.024 & 0.033 & 0.054 & 0.011 & 0.016 & 0.024 & 0.074 & 0.074 \\
\hline $\begin{array}{l}\text { Less than } 0.15 \mathrm{~g} \text { water absorption } \\
\text { through film after }\end{array}$ & $0.02 x$ & 31 & 143 & 31 & 143 & 143 & 143 & 143 \\
\hline $\begin{array}{l}\text { Less than } 0.25 \mathrm{~g} \text { water absorption } \\
\text { through film after }\end{array}$ & 8 & 35 & & 143 & & & & \\
\hline $\begin{array}{l}\text { Less than } 0.50 \mathrm{~g} \text { water absorption } \\
\text { through film after }\end{array}$ & 8 & 39 & & & & & & \\
\hline $\begin{array}{l}\text { Less than } 1.00 \mathrm{~g} \text { water absorption } \\
\text { through film after }\end{array}$ & 8 & 143 & & & & & & \\
\hline $\begin{array}{l}\text { Less than } 1.50 \mathrm{~g} \text { water absorption } \\
\text { through film after }\end{array}$ & 10 & & & & & & & \\
\hline $\begin{array}{l}\text { Less than } 2.00 \mathrm{~g} \text { water absorption } \\
\text { through film after }\end{array}$ & 11 & & & & & & & \\
\hline $\begin{array}{l}\text { Less than } 2.50 \mathrm{~g} \text { water absorption } \\
\text { through film after }\end{array}$ & 12 & & & & & & & \\
\hline $\begin{array}{l}\text { Less than } 3.00 \mathrm{~g} \text { water absorption } \\
\text { through film after. }\end{array}$ & 12 & & & & & & & \\
\hline $\begin{array}{l}\text { More than } 3.00 \mathrm{~g} \text { water absorption } \\
\text { through film after. }\end{array}$ & 13 & & & & & & & \\
\hline
\end{tabular}

1 More than,

TABLE 5.-Permeability to moisture-accelerated cycle

\begin{tabular}{l|r|r|r|r}
\hline \multicolumn{1}{c|}{ Paint } & \multicolumn{3}{|c}{ Water absorbed by calcium chloride through coatings } \\
(grams)
\end{tabular}

The early stages of the above investigation were so encouraging that two paints were tested in a somewhat similar manner in the accelerated cycle (without refrigeration). For this test rectangular brass frames 7.5 by $15 \mathrm{~cm}$ to hold the No. 100 sieve cloth were prepared and three coats of the paint applied as before. Permeability was determined by clamping a glass weighing tube containing $\mathrm{CaCl}_{2}$ to the cloth, using rubber washers to make tight joints. The results are shown in Table 5. Here again the results are what experience with these paints would indicate. 


\section{PERMEABILITY TO AIR}

This work on sieve cloth was so encouraging that a number of similar panels were prepared, coated with various well-known paints, and subjected to the accelerated cycle. It was soon found, however, that the experimental errors were so large, owing to the small amount of water taken up and the difficulty of learning whether the joint between the film and the weighing tube was tight, that it was decided to abandon the gravimetric method and to use a method of measuring the air passing through the film under definite conditions. Apparatus for this had to be designed and made, and this took so much time that the exposure to the accelerated cycle had in many cases gone too far before any measurements were made.

Figure 5 is a photograph which shows the apparatus finally developed. $Y$ shows unpainted and painted wire sieve cloth in brass frames; $N$ and $R$ show bottom and top of a cell for holding the whole frame and to the left of $G$ a similar cell for clamping a portion of the painted gauze. Rubber gaskets on top and bottom of the gauze panels serve to make an air-tight connection when the cell is compressed in the arbor press $G$. The lower compartment in the cell is joined by an air-tight connection to one of the large burettes shown to the right of $G$ and the left of $W$. The water is adjusted to a mark in the upper constricted portion and with the cock in the upper portion of the cell closed the burette cock is opened. When water does not fall in two minutes below a zero mark on the burette (previously determined), the joint is considered tight. The cock in the upper part of the cell is then opened, the burette read after two minutes, and the volume recorded. The small cell has the disadvantage that at each test the painted gauze is compressed between rubber gaskets, and the advantage that three readings can be made on each panel. The large cell, $R$ and $N$ (which on account of the difference in volume gives a different zero point on the burette), with the bolted type of frame shown in the figure, is very difficult to make tight. With frames soldered on the edges instead of bolted, tight joints can be made with this cell. It has the advantage of not compressing the test film and the disadvantage of giving only one reading on each panel.

Since all of the paints were applied to the bolted panels, the small cell was used, and three readings were taken on each panel or six on each paint.

The exposures to the accelerated cycle were started July 19, 1927. After one month panels 7 and 8 (lithopone linseed-oil paint) showed such complete disintegration by visual inspection that they were 
removed from the test and kept in a clean, dry container. The remaining panels were subjected to the accelerated cycle for four months. The permeability tests were made November 21, 1927. The results are shown in Table 6.

TABLE 6.-Permeability of various paints after four months in accelerated cycle

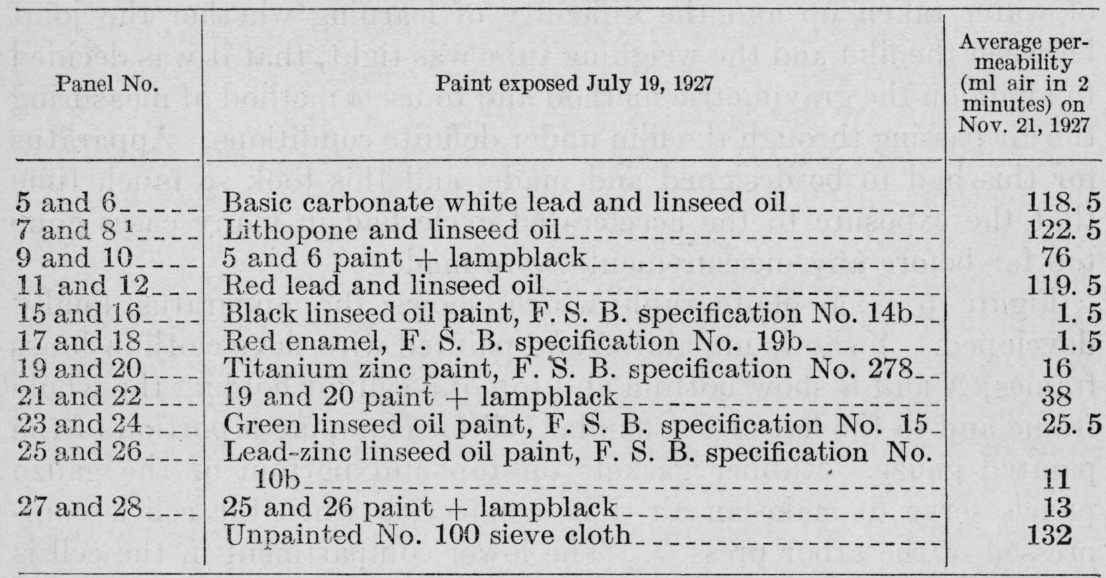

1 These panels were exposed exactly 1 month and then discontinued, because under the microscope the coating was cracked all over. They were by far worse than any other panels.

In general, these results confirm the other experiments in indicating that the method is valuable. The lithopone paint which shows up worst in the test is known to be a paint of poor durability. Black linseed oil paint is known to be one of the most durable paints. The red enamel, which is the only paint equaling the black in this test, is also a very durable paint. The slightly better showing of the untinted titanium zinc and lead zinc paints as compared with the same paints tinted is not what would be expected. It is possible that longer exposure may show different results with these; for this reason these discrepancies are not considered of any moment. The decided breakdown of red lead as compared with two of the white paints suggests that the supporting surface may influence the results. It is possible that bronze wire screen has some deleterious effect on red lead-linseed oil paint. It is clear that more work must be done with this method of determining the end point of paint failures before a positive opinion as to its real value can be expressed. However, the results as a whole are encouraging, and we expect to repeat some of the work in Table 6, and since the nature of the wire gauze may influence the behavior of some paints it is proposed to apply paints to cotton cloth as well as to wire gauze. 


\section{ELECTRICAL CONDUCTIVITY TEST}

On August 31, 1927, Doctor Liebrich and Doctor Kerscka, of the Chemisch-Technische Reichsanstalt, Berlin, showed one of the writers a simple apparatus for testing the continuity of an insulating film on metal. A telephone receiver is connected with the back (unpainted) side of the steel panel. A voltage from an interrupted source is placed across the receiver, and the return wire ending with a fine metal brush is drawn across the painted surface. Breaks in the paint surface are indicated by a buzz in the telephone.

J. H. Wilson, assistant chemist in this laboratory, has investigated this method. He found that the simple brush used by Liebrich and Kerscka would detect rather large uncovered areas but would not detect many of the visible cracks. Wilson has, however, modified the method by placing drops of a conducting liquid that will readily wet the coating on the painted surface and completing the circuit by dipping the end of the wire in these drops. The test panel, after some of the paint is scraped from the back side, is laid on a frame of metal wool, which is connected with one lead from the battery, and evenly spotted with the conducting liquid with the rubber stamp ( $F$ in fig. 6 ). After about two minutes the platinum tip of the other lead is inserted in each of the drops. Since there are 50 drops, the number of buzzes multiplied by two gives the percentage of breakdown.

Ten commercial samples of olive green automobile enamels (oleoresinous type) were tested on 7.5 by $15 \mathrm{~cm}$ black iron panels. Three coats, allowing one week between coats, were applied to all panels, four panels being prepared with each sample. Two of these four panels were subjected to the accelerated cycle (without refrigeration) and two were exposed outdoors $45^{\circ}$ to the vertical, facing south. The exposures were started in March, 1927. The accelerated tests were rated by inspection after 10 days. The outdoor tests were rated by inspection after one month. The accelerated tests were then continued for a total of 35 days and the outdoor tests for 146. After 35 days' accelerated testing each panel showed by inspection greater deterioration than the corresponding 146-day outdoor panel.

They were then tested using Wilson's method. A summary of the results is given in Table 7 . 
TABLE 7.-Tests of olive green oleoresinous automobile enamels

\begin{tabular}{|c|c|c|c|c|c|}
\hline \multirow[b]{2}{*}{ No. } & \multirow{2}{*}{$\begin{array}{l}\text { Composite } \\
\text { rating on loss } \\
\text { of gloss, dis- } \\
\text { coloration, } \\
\text { chalking, and } \\
\text { cracking after } \\
10 \text { days' accel- } \\
\text { erated test }\end{array}$} & \multirow[b]{2}{*}{$\begin{array}{l}\text { Rating on crack- } \\
\text { ing alone after } 10 \\
\text { days' aceelerated } \\
\text { test. In the } \\
\text { columns marked } \\
\text { on scale of } 10 \\
1 \text { being best }\end{array}$} & \multirow[b]{2}{*}{$\begin{array}{l}\text { Rating after one month } \\
\text { outdoor exposure }\end{array}$} & \multicolumn{2}{|c|}{$\begin{array}{l}\text { Rating by Wilson's test, per } \\
\text { cent destruction }\end{array}$} \\
\hline & & & & $\begin{array}{c}\text { Accelerated } \\
\text { panels after } 35 \\
\text { days' accelerated } \\
\text { test and storing } \\
\text { in clean, dry } \\
\text { compartment }\end{array}$ & $\begin{array}{c}\text { Outdoor } \\
\text { panels after } \\
146 \text { days' } \\
\text { exposure and } \\
\text { storing in } \\
\text { clean dry } \\
\text { compartment }\end{array}$ \\
\hline 1 & A & 1 & No change- & 20 & \\
\hline 2 & $\mathrm{~B}$ & $11 / 2$ & Film whitened. & 12 & \\
\hline 3 & A & $1^{2}$ & No change & 34 & 2 \\
\hline 4 & C & 7 & Checked all over_ & 100 & $9 \overline{2}$ \\
\hline 5 & A & 1 & No change....... & 14 & \\
\hline 6 & B & 6 & $\ldots$ do & 52 & 6 \\
\hline & $\bar{A}$ & 4 & & 14 & \\
\hline 8 & $\bar{C}$ & 9 & Checked all over & 100 & 58 \\
\hline 9 & C & 9 & - & 100 & 32 \\
\hline 10 & A & 1 & No change....... & 40 & \\
\hline
\end{tabular}

$A=0$ ne of five best.

$\mathrm{B}=$ Intermediate.

$\mathbf{C}=$ One of three worst.

This test and similar results obtained with various bituminous materials on aluminum indicate that this method is very useful for recording the failure of protective coatings on metal. The method is rapid and, with proper care, quite easy of execution. It is important, however, to select a suitable wetting liquid. For glossy, hard coatings that have a tendency to repel water a dilute ( 0.5 per cent) soap solution is generally suitable. On chalky, soft films this solution spreads so rapidly that the individual drops flow together before the contacts can be made. For such coatings a dilute ( 0.5 per cent) solution of sodium chloride is generally suitable.

This test can be applied to almost all organic coatings for steel. Aluminum paint, however, has been found to be a sufficiently good conductor to give a buzz even when there is no break in the film. Other such coatings may be found, hence one should make sure that the undamaged coating does not cause a buzz before using this test. As may be expected, the intensity of the buzz given by the different drops varies greatly. However, the method gave good results.

\section{USE OF MILLIAMMETER}

It seemed desirable to the authors to obtain some quantitative measure of the current passing through various sections of the paint coatings. With valuable assistance from C. M. Saeger, jr., the following methods were used: A milliammeter, having a scale reading from 0 to 60 milliamperes, was connected in series with a battery and the test specimen. The current was adjusted with a resistance 
so that a bare metal panel gave a reading of nearly 60 on the scale. Freshly painted panels gave readings of zero. Exposed panels that were still in good condition gave readings of 2 or 3 milliamperes, while badly cracked coatings gave readings as high as 50 milliamperes. It was decided to reduce the total number of spots to be tested from 50 to 12 , but to increase the diameter of the spots from approximately 8 to $12.2 \mathrm{~mm}$ ( $0.5 \mathrm{inch})$. These spots were equally distributed over a test area measuring 5 by $12.7 \mathrm{~cm}$ ( 2 by 5 inches). Previously some trouble was caused by the electrolyte disappearing after being stamped on the panel. This took place particularly on chalky, porous coatings. To overcome this trouble, a measured volume (about $0.1 \mathrm{ml}$ ) of the electrolyte was applied to a test area, and after one minute a reading was taken before applying the electrolyte to the next area. This method gave good results.

In order, however, to keep the diameter of the wetted spot exactly the same in all cases, it was finally decided to use a porous or spongy material in contact with the specimen during the test. A satisfactory material was a mixture of silica sand (free from clay) and rubber cement. This was molded into a cylinder $12.2 \mathrm{~mm}(0.5$ inch) in diameter by $76.2 \mathrm{~mm}$ (3 inches) long. A copper terminal was embedded in this electrode. This was placed in a small glass cell containing the electrolyte. The electrode was found to have excellent capillary attraction. In making a test the painted side of the specimen was placed on top of the electrode for one minute before applying the current from the battery. This method of applying the electrolyte gave wetted spots having the same diameter and proved satisfactory. No trouble was experienced in obtaining readings that could be checked. It is possible to have either a single electrode and test the specimen in definite positions or to have a number of electrodes (about 12) in a fixed position and set the specimen on these. The condition of the battery and the electrical connections can be checked by noting the milliammeter reading on a standard bare plate before and at the end of a test. After finishing with the test specimens they were rinsed with clean water and returned to the exposure cycle.

\section{QUALITATIVE METHOD FOR DETECTING PINHOLES, ETC., IN PAINT COATINGS}

The usual practice in preparing paint panels for exposure tests is to apply several coatings and then assume that the panel is completely covered. It seemed desirable to apply some simple and rapid test to the coated area to prove that the metal was entirely coated. $2284^{\circ}-28-2$ 
The improved ferroxyl test of Pitschner ${ }^{9}$ for detecting the porosity of electroplated coatings on ferrous metals was first tried on electroplated articles with excellent results. In attempting to adapt this test to paint coatings, it was found that the "ferroxyl" reagent on the paper was apparently repelled by the paint coatings. This possibly could be corrected by experimenting, but no further work was done with the method. The idea of Pitschner of using coated paper for his studies on electroplated material led the authors to try various methods for obtaining results. The following method was found rapid and satisfactory. Sheets of filter paper, or any good grade of unsized bond paper, are cut into proper sizes for the test panels 7.5 by $15 \mathrm{~cm}$. In applying the test, one of the sheets is immersed in a weak ( 0.5 per cent) sodium chloride solution containing a few drops of phenolphthalein indicator $(0.1$ per cent alcoholic solution). The paper, moistened on both sides, is spread over the coated specimen, avoiding air pockets. Connection with a dry cell is made to the bottom of the plate and an electrode from the negative pole passed across the wetted paper. Within a few seconds, an intense red shows on the white paper if any bare metal is present. Pinholes, etc., can be accurately located. Invariably it was found that the edges of freshly painted panels gave a fine red line the length of the panel. It is well known that the edges of metal panels are generally the first parts to show corrosion. Cracks on weathered panels are readily located by the method. The print, likewise, gives a good quantitative idea of the number and size of the cracks. After the test the panels are washed in clean water and allowed to dry.

It is intended that these quantitative methods should supplement the usual practice of visual inspection of the appearance of the coatings, including such important properties as change in color, loss of gloss, surface checks, wrinkles, etc.

\section{SUMMARY}

Apparatus for exposing organic protective coatings to artificial light, water, and gases is described.

A variety of materials, including varnishes, oil paints, enamel paints, lacquers, bituminous saturated felts, bituminous roofing materials, have been tested in a proposed accelerated cycle. As judged by visual inspection the nature of the breakdown is remarkably similar to the breakdown of the various materials on weathering. There is chalking with paints that chalk in service, cracking with those that crack, and similar changes in color. The characteristic differences in behavior of various asphaltic mixtures observed on outdoor weathering are duplicated in the accelerated cycle. The same may

'Karl Pitschner, "A rapid and practical method of applying the ferroxyl test to protective coatings," Proc. Am. Soc. Test. Mtls., 27, Pt. II, p. 304; 1927. 
be said of varnishes and lacquers. In fact, the duplication of weather effects has been remarkable with all types of materials tested.

While failure in the accelerated cycle is similar to and more rapid than that on weather exposure, no definite ratio has as yet been fixed between the accelerated test and weather test. This is readily evident from a consideration of the variations in the weather.

The difficulty of determining the relative condition of protective coatings is discussed, and the unreliability of opinions based on visual inspection is pointed out. Several methods of quantitatively measuring the extent of failure of such coatings are described. These include measuring the amount of water vapor under definite conditions or amount of air under definite pressure passing through coating on wire gauze and several plans of locating and measuring breaks in a coating on metal by electrical means.

The writers gratefully acknowledge the work of B. H. Carroll in photographing the comparative spectra shown in Figure 1, and of W. W. Coblentz in determining the total radiation and spectral distribution given in Table 1.

Washington, February 25, 1928. 
